\title{
Archibald Leman Cochrane 1909-1988: a meaningful life in science and history
}

Andre Breton, and the surrealist movement, called a livreobjet, a book that was a piece of art in its form and not only in its content (Picture 1). Xavier Bosch has produced a wonderful livre-objet on Archie Cochrane, entitled: "Archibald Cochrane: back to the front" (Picture 2) (Bosch 2003). It has pictures, testimonies, citations of historians and novelists. The book is a passionate tribute to Archie Cochrane, the British epidemiologist whose name has become the rallying point of people throughout the world who collaborate to prepare, maintain, and disseminate systematic reviews of the effects of healthcare interventions.

The title "Back to the front" may sound surprising for the biography of an epidemiologist. Which front? Which battle? Actually, there were many fronts and many battles in Cochrane's life.

The first took place in 1937 Catalonia, when Cochrane joined the Republicans to fight the anti-democratic army led by General Bahamonde Franco. This was a very dramatic moment in European history. In the 1930s, Hitler had seized power in Germany, and Mussolini in Italy. Franco, following their path, was attempting to defeat the young Spanish Republic. The leftist parties, mainly the communists, organized groups of volunteers to go and fight on the side of the republicans. Others went to Spain spontaneously. Between the autumn of 1936 and the autumn of 1938, about 50000 volunteers joined these International Brigades. Their premises were right.

At the very beginning of his military rebellion, Franco would have had no chance to overthrowing the young Republic had he not had massive help from the fascist governments in Germany and Italy (Bolloten 1991).

In July 1936, the Spanish navy had refused to join the seditious officer corps, so that Franco depended entirely on the pilots and planes provided by Hitler and Mussolini to enable his African Army to cross the Strait of Gibraltar (Bolloten 1991). On the other hand, no government appeared ready to help the legal Republican authorities sufficiently to enable them to win the war. Even the soviet republic, the USSR, which had been the strongest supplier in experts and resources, limited its help to what was needed to prevent the collapse of the Republic, not to guarantee its victory. The International Brigades fought in Spain for about two years. They made an impressive contribution to the defense of Madrid from the autumn of 1936 to the spring of 1937 (Bolloten 1991).

Among those who went to Spain to defend the Republic was Archie Cochrane. He had driven there in his car and served as a doctor. He was one of a generation of young British doc-

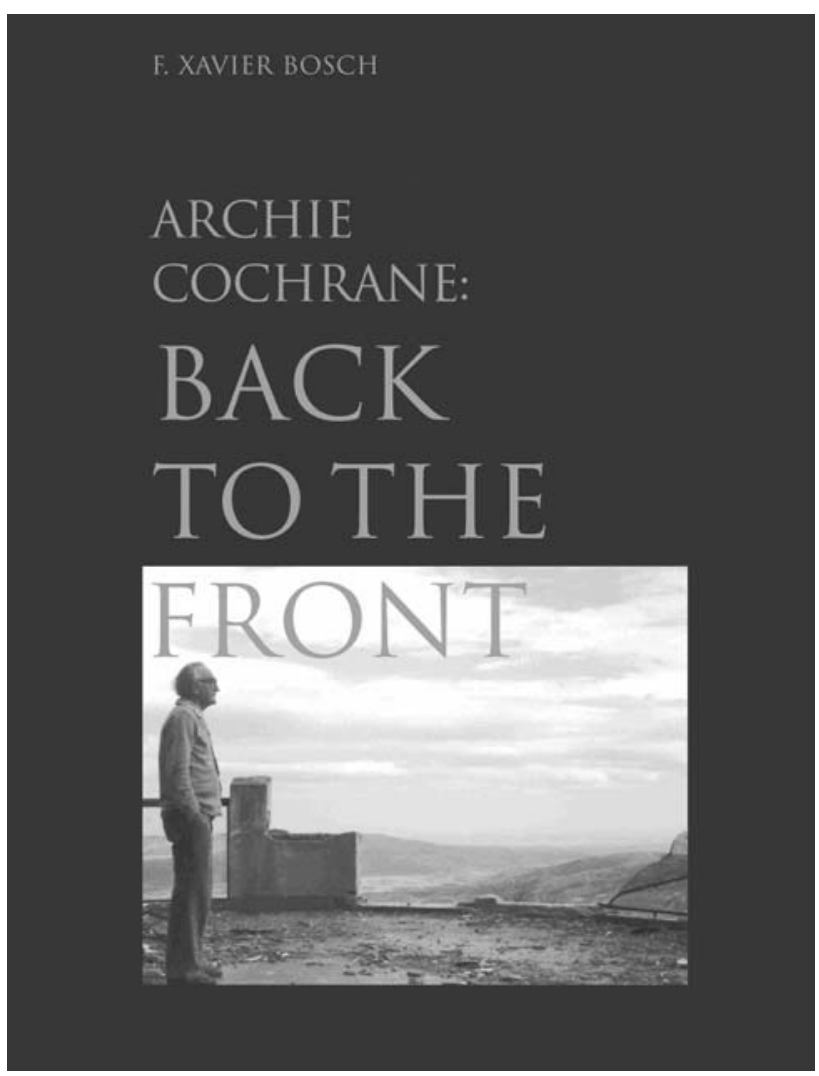


tors, and more generally scientists, in the 1930s believing in social justice and willing to combat fascism actively. In this context Cochrane and other epidemiologists-to-be emerged as militants acting in solidarity with the Spanish Republic. Among them was Sir Richard Doll who tells his own story in the book (Bosch 2003).

But the sacrifices of the International Brigades were wasted. Since August-September 1936, abandoning the Republic, Britain and France had called for all countries in Europe not to intervene in the Spanish Civil War. Eventually 27 countries including France, Britain, Belgium, Netherlands, Russia, the Soviet Union, Portugal and Sweden joined this Non-Intervention Committee. Germany and Italy formally subscribed to the agreement. In September 1938, the withdrawal of foreign volunteers from Spain by the Republican authorities was a last, desperate attempt to win the support of the Western governments. The Republic collapsed, opening the way to the Second World War.

World War II started shortly after the final victory of Franco and created Cochrane's second front. He joined the army, was captured and became responsible for the health care of prisoners of war in Salonica, Greece. The book reproduces the section of Cochrane's autobiography (Cochrane \& Blythe 1989; Cochrane 1984) in which he tells the story of a therapeutic trial he conducted in the camp. When a number of men developed heavily swollen ankles, Archie diagnosed a protein deficiency and experimented to find the best treatment. Cochrane knew the story of James Lind, a Scottish naval doctor who, two centuries earlier, had reported a controlled comparison of treatments for scurvy, showing the effectiveness of oranges and lemons (Lind 1753). Cochrane was also aware of a disease called beriberi, stemming from a deficit in vitamin B. In 1929, Eijkman had received the Nobel Price for his groundbreaking laboratory experiments showing that beriberi was a nutritional disease (Carpenter 2000). A successful clinical test indicating that vitamin B1 was effective against beriberi was reported in 1937, while Cochrane was in Catalonia. Yeast is an important source of vitamin B1 and one of the best ways to treat a deficit. All this was in Cochrane's mind when he chose 20 men with severe swelling, and allocated them alternately to one or other of two small wards. Those in one ward received three daily portions of protein-rich yeast, which Cochrane had bought on the black market. Those in the other ward received one vitamin $\mathrm{C}$ tablet daily out of Archie's small emergency reserves. By the fourth day, eight out of 10 men in the yeast ward felt better, but no one in the vitamin C room. Here is Cochrane's own account of the episode:
"Then I remembered having read about 'wet beriberi' caused by vitamin B deficiency, which resulted in severe edema. For a time I must have convinced myself that I was witnessing an epidemic of 'wet beriberi', for I decided to do an experiment modeled on that of James Lind, one of my medical heroes. I chose 20 men, all in their early twenties, all emaciated and with edema above the knee. I put 10 in each of two small wards. They all received the standard rations, but those in one ward were given a supplement of yeast three times a day (I had to use my own reserve of Greek money to get it on the black market). In the other ward they got one vitamin $\mathrm{C}$ tablet each day (I had kept a small reserve for emergency). (...). Eight out of ten men in the 'yeast room' felt better, while no one felt better in the 'vitamin C room'."(Bosch 2003: 202-3).

After the war, Cochrane's front moved to Britain. The Spanish Civil War and of course World War II had resulted in a good deal of disillusionment among the young people who wished to see more social justice and democracy. But there were new opportunities in the British society, which had gone through a process of modernization since the mid1930s and had been able to mobilize its industry and its technological superiority (e.g., cars, radar, electric equipments, planes) for the war effort. Britain's war-planned economy had slanted towards social justice (Hobsbawm 1996). Keynes's economic theories suggesting that internal, statecontrolled mechanisms rather than colonial expansion and exploitation could foster economic growth were gaining audience (Keynes 1936). The 1942 Beveridge Report stated that: "Medical treatment covering all requirements will be provided for all citizens by a national health service organised under the health departments and post-medical rehabilitation treatment will be provided for all persons capable of profiting by it" (Beveridge 1942). Winston Churchill, a conservative and UK Prime Minister since 1940, lost British general election of July 1945 to Labour's Clement Attlee. The time had come to deliver social promises in practice. This idea was already present in a 1944 booklet entitled "Health" by Jerry Morris, later the author of the influential textbook "Uses of epidemiology": the world had to become better after the defeat of Hitlerism (Smith 2001). In this context, the internationalist generation of the 1930s refocused its energy, fighting for public health, more equality in the access to health care, and a National Health Service. Epidemiology provided the concepts and methods for pursuing these new objectives. The discipline helped to identify the modifiable causes of ill health, and to improve those living and occupational conditions which affected the poorer sectors of the society. The work of Austin Bradford Hill, Richard Doll, Jerry Morris, Archie Cochrane and many oth- 
ers, all more or less inspired by socialist ideals, is a testimony of this.

Greater social equity also meant better distribution of care. And in a country with limited resources (the UK had ceased to be, after World War II, the major economic power it once had been), better distribution meant identifying effective treatments and concentrating economic resources on these. The Beveridge Report should have referred to all "effective" treatments. This is the origin of Cochrane's campaign to evaluate treatment and preventive practices using appropriate methods, among which randomized controlled trials played a central role. On this new front, Cochrane was an efficient propagandist (Cochrane 1972), his ideas leading soon after his death to the international collaboration that bears his name.

When I closed "Back to the front", I had the feeling, wrongly or rightly, that the Spanish Civil War had played a pivotal role, not only in European history but also in the history of epidemiology. The 1930s released a tremendous energy in some sectors of European youth, which expressed itself in the anti-fascist solidarity and later in the fight against health inequalities. This lead to the emergence of a new generation of British epidemiologists, thanks to whom our discipline has reached unprecedented levels of rigor and theory and has started to play a major role for the public health.

In conclusion, here is a book with many facets. It is, first of all, the homage of free Catalan epidemiologists to a British epidemiologist who stood up for a free Catalonia. It is also a book about Archie Cochrane's contemporaries, a generation of British epidemiologists, which brought their discipline to new levels of efficiency and formalism and contributed to discoveries of great relevance to public health. It is finally a book on a person with a very unique personality, a romantic existence and inspiring ideas. Cochrane's was a life that made sense both in science and in history.

\section{Acknowledgements}

I am indepted to Jean Baton, Iain Chalmers, Michael Costanza, Miquel Porta and Séverine Schusselé-Filletaz for their insightful comments on an earlier version of this manuscript.

\section{References \\ Beveridge W (1942). Social and allied services (The Beveridge Report). http://www.fordham. edu/halsall/mod/1942beveridge.html. \\ Bolloten B (1991). The Spanish Civil War: revolution and counterrevolution. Chapel Hill: University of North Carolina Press. \\ Bosch FX (2003). Archie Cochrane: back to the front. Barcelona: Ajuntament de Barcelona, The Cochrane Collaboration, Institut Català d'Oncologia. \\ Carpenter KJ (2000). Beriberi, white rice, and vitamin B: a disease, a cause and a cure. Berkeley: University of California Press.}

Cochrane AL (1972). Effectiveness and efficiency: random reflections on health services. London: Nuffield Provincial Hospitals Trust.

Cochrane AL (1984). Sickness in Salonica: my first, worst, and most successful clinical trial. BMJ Clin Res Ed 289: 1726-7.

Cochrane AL, Blythe M (1989). One man's medicine: autobiography of professor Archie Cochrane (The Memoir Club). London: BMJ Publishing Group.

Hobsbawm E (1996). The age of extremes. New York: Vintage Books.

Keynes JM (1936). General theory of employment, interest and money. London: Macmillan Cambridge University Press for Royal Economic Society
Lind J (1753). A treatise of scurvy. Edinburgh: University Press (1953)

Smith GD (2001). The uses of "Uses of epidemiology”. Int J Epidemiol 30: 1146-55.

Address for correspondence

Prof. Alfredo Morabia Serrice d'épidémiologie clinique 25 Rue Micheli-du-Crest 1205 Geneva Switzerland e-mail: alfredo.morabia@hcnge.ch 